"Impact of climate change and natural catastrophe on the occupational changes in the coastal areas of Bangladesh: an empirical study"

\begin{tabular}{ll} 
AUTHORS & Nawazeesh Muhammad Ali \\
\hline ARTICLE INFO & $\begin{array}{l}\text { Nawazeesh Muhammad Ali (2018). Impact of climate change and natural } \\
\text { catastrophe on the occupational changes in the coastal areas of Bangladesh: an } \\
\text { empirical study. Environmental Economics, 9(1), 22-37. } \\
\text { doi:10.21511/ee.09(1).2018.02 }\end{array}$ \\
\hline DOI & http://dx.doi.org/10.21511/ee.09(1).2018.02 \\
\hline RELEASED ON & Tuesday, 06 February 2018 \\
\hline RECEIVED ON & Thursday, 28 December 2017 \\
\hline ACCEPTED ON & Monday, 29 January 2018 \\
\hline LICENSE & $\begin{array}{l}\text { (co) EY-No } \\
\text { Inis work is licensed under a Creative Commons Attribution-NonCommercial } 4.0\end{array}$ \\
\hline JOURNAL & "Environmental Economics" \\
\hline ISSN PRINT & $1998-6041$ \\
\hline ISSN ONLINE & $1998-605 X$ \\
\hline PUBLISHER & LLC “Consulting Publishing Company "Business Perspectives" \\
\hline FOUNDER & LLC "Consulting Publishing Company "Business Perspectives"
\end{tabular}

NUMBER OF REFERENCES

42

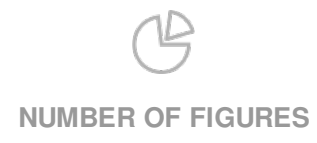

2
NUMBER OF TABLES

4

(C) The author(s) 2022. This publication is an open access article. 
Nawazeesh Muhammad Ali (Bangladesh)

\title{
Impact of climate change and natural catastrophe on the occupational changes in the coastal areas of Bangladesh: an empirical study
}

\begin{abstract}
Occupation of the populace who live in the coastal areas of Bangladesh needs to be changed in the pattern of source of income owing to sea level rise and natural disaster in a cyclical manner and also irregular variations. This is now a great concern for Bangladesh especially in the country's coastal regions. As such, the research question relates to assessing the impact of climate change and natural catastrophe on the occupational changes in the coastal areas of Bangladesh. This study explored using both primary and secondary sources. The study had been conducted from May to December 2017. The study found that climate change was causing sea level raising and created salinity problem in the coastal areas, which has caused change of the occupational changes. Salinity problem had caused damage of most of the agricultural production, fisheries and household. The binary logistic regression equation indicated that occupational change was due to climate change and natural catastrophe that also depend on socio-economic situation of the people of that area of the country. From another binary logistic regression equation, it was found that occupational change also depends on the various demographic factors and if the personal position of the respondents is changed then it will occur. Each year in coastal areas, people are permanently and temporarily dispersed because of global warming in Bangladesh. The country should take effective steps in the coastal areas to diminish climate change threat and also control over its phenomenon. Those who are responsible internally to increase climate change should be supported by creating employment opportunities for affecting community development as suggested by the researcher. To reduce natural catastrophe, more trees should be planted in the coastal regions, and there is a need in balanced development at urban and rural areas without destroying nature.
\end{abstract}

Keywords: occupational change, scarcity, environmental modification, relocation, coastal regions.

JEL Classification: Q54, I30.

Received on: $28^{\text {th }}$ of December, 2017.

Accepted on: $29^{\text {th }}$ of January, 2018.

\section{Introduction}

Bangladesh is in a risk owing to the shock of climate change and natural catastrophe over the time period. The climatic conditions are influenced by the environmental location and low land of the Ganges Delta in which the flooding and loss of land are due to sea level rise. Climate change and natural catastrophe have been causing occupational changes in the country. Ahmed (2009) commented that "A long-term study is needed to understand the potential threats of sea level rise to coastal areas of Bangladesh and to formulate appropriate mitigation measure to eliminate or reduce the adverse impacts".

According to Financial Express (November, 18, 2017) about Bangladesh "In its latest Global Climate Risk Index 2018, the country remains in the

\section{(C) Nawazeesh Muhammad Ali, 2018}

Nawazeesh Muhammad Ali, Master in Development Studies (MDS), American International University-Bangladesh and Research Associate Center for Breakthrough Thinking in Bangladesh, Bangladesh.

This is an Open Access article, distributed under the terms of the Creative Commons Attribution-NonCommercial 4.0 International license, which permits re-use, distribution, and reproduction, provided the materials aren't used for commercial purposes and the original work is properly cited. sixth position among countries most affected during the period 1997-2016". National Environmental Policy of the country was declared in the year 1992, but needs an update.

Determination is a prerequisite to be completed to define the economic prices of the effects of climate change on the country. As Alam (2013) described, "livelihood is interrelated with social, ecological and intuitional drivers which imply innate capacity of the coastal community that enables or constrain their ion adapt to changing situation". Bangladesh is one of the most affected by climate change effects which sometimes change the occupational pattern of the people of the related areas or create unemployment.

Occupational changes depend on the following factors:

- Employment type.

- Food taking style.

- Variation in job.

- Environmental migration.

- Income source change.

Coastal ecosystems are areas where land and water together can create an environment with a diverse organization, variety, and tide energy. They include 
salt marshes, mangroves, lands, inlets, and bays and are home to numerous dissimilar types of floras and creatures. Climate change has harmful effects on people's health and communities which are: sea level increase is speeding up; number of large wildfires is growing; risky heat waves are flattering more frequent; by dangerous storm measures are mounting in many areas; more severe droughts are stirring in others.

Research question of the study is to assess the impact of climate change and natural catastrophe on the occupational changes at the coastal areas of Bangladesh.

\section{Literature review}

As per the research question, the study tried to do the literature review.

Ahmed (2002) commented that "The river bank erosion has an impact such as displacement of huge population and this makes the affected people unemployed which has an impact on the urban centers, particularly Dhaka, through mitigation". As Agrawala et al. (2003) described "Bangladesh is the number one catastrophe vulnerable country in the world". Selvaraju et al. (2006) opine that "A livelihoods approach puts climate-related vulnerabilities within the context of the overall vulnerabilities that poor people face". A study of Khan et al. (2013) found that "impact of displacement has occurred in the livelihood pattern". Haque (2006) observed "the coastal areas of Bangladesh contain more than $30 \%$ of country's cultivable land. Tidal and estuarine flood plains cover $98 \%$ of this $30 \%$ of total area of the coastal belt". Ali and Wakatsuki (2002) commented that "The average crop yields are very low now in these coastal belt regions resulting from salinity problems, land erosion, flooding, low soil fertility and drought in the dry season".

Islam (2016) observed that in Bangladesh "The number of affected people will be 2.5 lakh, 6 lakh and 8 lakh for the $0.5 \mathrm{~m}, 1 \mathrm{~m}$ and $1.5 \mathrm{~m}$ SLR. The biggest threat of SLR is on the largest mangrove forest of the world, the Sundarbans".

Shamsuddoha and Chowdhury (2007) described "coastal ecosystem as a potential source of natural resources, diversified fauna and flora composition, though there also exists in immense risk of natural catastrophes". Akther (2013) commented that "...Climate change will steadily increase the exposure of poor and vulnerable people to climate at Bangladesh causing shocks and increased pressure on coping strategies, which over time could steadily erode human capabilities". Adam-Poupart et al.
(2013) commented that "Sizeable challenges will have to be faced as numerous emerging problems which will probably impact on the work environment. Each problem will have to be examined taking often conflicting environmental, social, and economic constraints into account". Stavins et al. (2013) depicted that "much economic analysis has long focused on potential rather than actual Pareto improvements, leaving the allocation of net gains among individuals to the potential process similar reasoning may lead to an analogous approach to sustainability debates".

Kabir (2014) opines that "The gradual rise of average air and oceanic temperatures will change the rainfall patterns, and droughts and heat waves wich intensify tropical cyclones, floods and increase sea levels leave at the mercy of the forces of nature in Bangladesh". Lasco et al. (2014) identified "challenges in the promotion and adoption of agroforestry at the farm and landscape levels as a climate change adaptation strategy".

Lázár et al. (2015) argued that "livelihood changes of farmers may occur as a result of climate and environmental change using an innovative prototype model".

Wright (2015) argued as per recent IPCC report that "By 2050, Bangladesh's population at risk of sea level rise is predicted to rise to 27 million. ... Climate change also poses risks for food security. The report says that under a scenario of low crop productivity, Bangladesh could experience a net increase of poverty of $15 \%$ by 2030 ".

Dasgupta et al. (2016) observed that for Bangladesh "urban migration of working-age family members as both an income source and the only feasible form of catastrophe insurance for coastal households. ...A strong link of rural (coastal areas) to urban migration occur due to climate change in the country".

Ahmad (2017) argued that "as people are the direct suffers as a result of floods and since they have been making responses, traditionally they, can improve their performance by substantially reducing losses, damages and sufferings by working within a community-level institutional framework". Johnson (2017) opine that "As climate change does not respect internationally recognized borders, it is crucial for the stability and prosperity of all nations that governments, development institutions, and NGOs work together to provide the best practices and policies to both mitigate and adapt to these challenges". 
Rojas-Downing et al. (2017) depicted that "Livestock production will be limited by climate variability as animal water consumption is expected to increase by a factor of three, demand for agricultural lands will increase due to the need for $70 \%$ growth in production, and food security concern since about one-third of the global cereal harvest is used for livestock feed".
From the study, it is clearly evident that climate change and natural catastrophe caused at coastal regions of Bangladesh work as a push factor to change in livelihood.

On the basis of the literature review the following conceptual framework was being prepared which is shown at Figure 1.

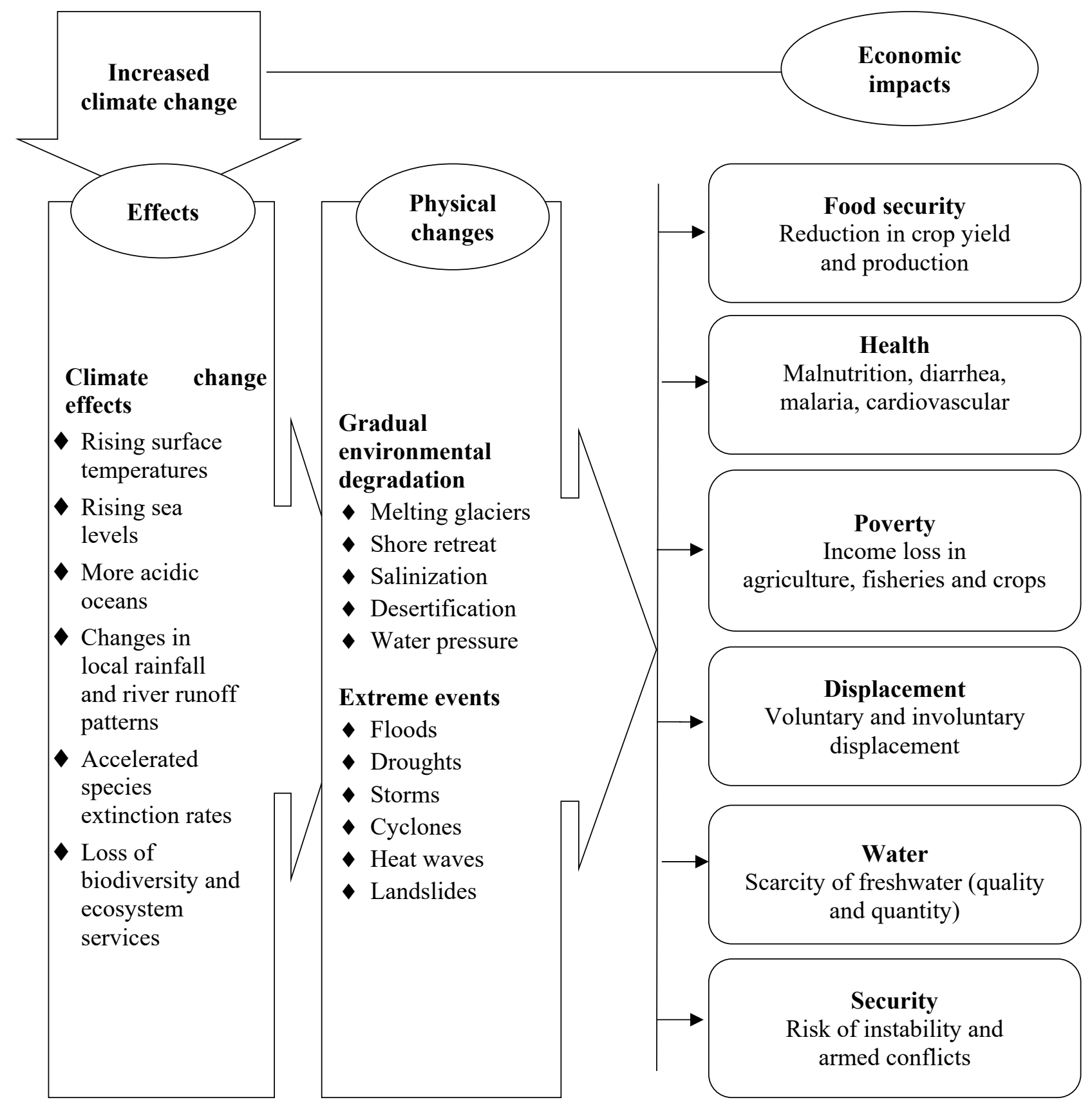

Fig. 1. Conceptual framework of the study

Source: Prepared by the researcher.

In the conceptual framework, the study tried to describe relationship between increased Climate change including physical changes, food security, poverty, water, displacement and security. Due to such Climate change ultimately people of the coastal area may suffer and they had to change their livelihood.

\section{Objectives}

Objectives are given below:

i. To ascertain occupational changes due to natural catastrophe and climate change at coastal regions of Bangladesh. 
ii. To find out recent situation of the community of the coastal areas of Bangladesh.

iii. To determine the economic influences of environmental modification in the coastal areas of the country.

iv. To provide some recommendations.

\section{Methodology}

Three regions at coastal area of the country i.e. Cox's Bazar, sandip of Chittagong District, kukata of Patukhlia Districts, respectively, were selected. The study selected these three district because they are very close to the Bay-of-Bengal and previously much more natural catastrophes have occurred and also every year the people of this area were suffering from many catastrophes caused by the climate change. Secondary sources were also considered.

Some specifications were done, e.g. (i) both men and women respondents were considered; (ii) the respondents must belong to catastrophe-prone area; (iii) from each household only one individual was measured; and (iv) the respondents must live in the selected study area for at least 5 years; (v) first tried to get response from the head of the household but in case of absence of the one who got National Identification Number, the study considered that person.

Using the purposive sample size determination, in total, 120 male and female respondents, were selected for study.

Primary data were collected through the questionnaire designed with open- and close-ended questions taking into consideration the economic effect of climate change on the coastal area of Bangladesh. An interview schedule contained. The study did the following two binary logistic regressions:

Occupational change due to natural catastrophe/Climate change $=f$ (Types of toilet/latrine facilities, Sources of income, Source of energy, Source of drinking water, Ownership of residence)

Occupational change due to natural catastrophe/Climate change $=f$ (Gender, Educational status, Family member, Family type, Occupation, Expenditure on education, Expenditure on health/medicine)

The study also did reliability test for secondary sources.

The study had been conducted from May to December 2017. A total number of 120 respondents include both male and female. Respondents were interviewed by the researcher. Data had been collected from July 01 to September 22, 2017. From October to December 2017 the study did editing, coding, and tabulation. Also the research-based article was written. The researcher visited the three districts and collected data by face-to-face interview.

Processed data had been analyzed and interpreted by using the appropriate statistical techniques, both descriptive, as well as inferential statistics regarding the objectives of the study. The study also determines correlation between the following variables based on primary data.

In descriptive statistics, e.g. frequency distribution and percentage were done. SPSS 20 was used for inferential, as well as descriptive statistical calculations.

To conduct the study, the study collected the data from two major sources. Those two sources helped us to conduct this study. Based on secondary sources, the study will do ordinary least square regression equation.

$$
\begin{aligned}
& P D=f(\text { Year }) \\
& P D=\alpha+\beta \text { Year }+\mu,
\end{aligned}
$$

where $P D=$ Permanent Dispersion,

$\mu=$ Error term.

$T D=f($ Year $)$,

where $T D=$ Temporary Dispersion,

$T D=\mathrm{f}($ Year $)$,

$T D=\alpha+\beta$ Year $+\mu$,

where $T D=$ Temporary Dispersion,

$\mu=$ Error term.

The study also converted current 8 divisions to older four divisions' to determine correlation matrix to assess all sorts of catastrophes.

\section{Hypotheses testing}

Alternative hypothesis (H1): Occupational change due to natural catastrophe/Climate change is related to Types of toilet/latrine facilities, Sources of income, Source of energy, Source of drinking water, Ownership of residence.

Alternative hypothesis (H2): Occupational change due to natural catastrophe/Climate change is related to Gender, Educational status, Family member, Family type, Occupation, Expenditure on education, and Expenditure on health/medicine.

Alternative hypothesis (H3): Permanent Dispersion has occurred due to Climate change. 
Alternative hypothesis (H4): Temporary Dispersion has occurred due to Climate change.

\section{Analysis of findings}

Based on data collection the demographic information described below is given in Table 1 in Appendix.

In Table 1, the average age of the respondents of sample group is 37 years but here is high deviation so this average age can't represent the whole sample group. Gender distribution of the respondents shows that in this study, $75.8 \%$ respondents are male and another $24.2 \%$ respondents are female. The study found that highest percentage $(80.8 \%)$ is for married. The majority $(74.2 \%)$ of the whole respondents response are in the medium range (5-7 members) of family size. For $24.2 \%$ respondents in the study, day labor was then source of income and this is the highest range of the whole categories. Highest $41.7 \%$ respondents' monthly family income was within 5001-10000 BDT. Family head of the households in coastal area of Bangladesh was the highest number $(50.8 \%)$ in the criteria of self while as the head of their household. The majority of the household heads (46.7\%) completed primary level education. Most of the household heads (39.2\%) are farmers while only 6.7 percent of heads were engaged with various types of job. The largest portion $(35 \%)$ of the households lived in Jhupri/hut. The highest $(57.5 \%)$ percent of households had the income (10001-15000 BDT). Maximum percent $(67.5 \%)$ of households have the expenditure level on food under $5001-8000$ BDT per month. About $58.3 \%$ of households have the expenditure level on clothes above 500 BDT and the rest (41.7\%) have below 500 BDT for purchasing clothes. $30.8 \%$ of households have the expenditure level below 500 BDT per month and about $28.3 \%$ have under 501-1000 BDT per month for education purposes. Around half $(45.8 \%)$ of the households of the coastal area have costs below 1000 BDT per month for health/medicine purpose. Maximum persent $(73.3 \%)$ of people of the coastal area live in their own house. More than half $(59.2 \%)$ of the respondents of the coastal area of Bangladesh drink water from tube well and about $24.2 \%$ people drink from deep well. Maximum percent $(57.5 \%)$ of household income depends on agriculture. About $60.0 \%$ households get energy from electricity and only $9.2 \%$ households get it from solar power. Maximum percent (93.3\%) of people used wood/bamboo for cooking; about $50 \%$ people also used cow dung for cooking. Nearly half (45.8\%) of the people agree that climate change increases and about $31.7 \%$ people strongly agree. More than half $(60.8 \%)$ of the people have thought that the natural catastrophes are occurring due to climate change. Half $(51.7 \%)$ of the respondents said that their residence, cowshed and kitchen are often damaged Maximum percent (76.7\%) of people of the coastal area told that the season of Bangladesh was changed since 2000 . Nearly half $(53.3 \%)$ of people told that their agricultural production decreased for the season change. $46.7 \%$ of people told that there is the case of frequently occurred water logging and $30.0 \%$ people about that very frequently occurred water logging in the coastal area of Bangladesh. The majority of the people $(87.5 \%)$ of the coastal area told that their domestic animals were damaged in the time when the natural catastrophe happened. Most of the people (89.17\%) in the coastal area told that different types of diseases are increasing at the time of the natural catastrophe and the rest $(10.83 \%)$ told that the frequency of illness was increasing due to natural catastrophe. Maximum percent $(63.3 \%)$ of people agreed and $24.2 \%$ people also strongly agreed that their occupational change occurred for the natural catastrophe or climate change. As such, the study can say that occupational change due to natural catastrophe/climate change is related to types of toilet/latrine facilities, sources of income, source of energy, source of drinking water, ownership of residence, which implies an alternative hypothesis.

Table 1 implies to the standard binary regressions of socio-economic condition and occupational change. Part i, of the table entitled variables entered/removed tells us about the independent and dependent variables and the regression method used. The adjusted R-Square value, in this case, is .139. This tells us that the five independent variables in our model account for $13.9 \%$ variance in the dependent variable that is occupational change. Based on the ANOVA table for the binary logistic regression, the study says that this regression model fits in $.004(p<0.005)$ level of significance.

Using the regression coefficients for independent variables and the constant term given under the column labeled B, one can construct the binary logistic regression equation for predicting occupational change as:

Occupational change $=4.336-($.350) [Ownership of residence $]-($.213) [Source of drinking water] + (.093) [Sources of income] - (.028) [Source of energy] + (.311) [Types of toilet/latrine facilities]

The $p$ value for beta coefficient of Ownership of residence is $.001(\mathrm{p}<0.001)$, Source of drinking water is $.079(\mathrm{p}<0.08)$, Sources of income is .204 $(p<0.20)$, Source of energy is $.709(p<0.70)$ and Types of toilet/latrine facilities is $.001(\mathrm{p}<0.001)$. Among these five independent variables, one 
variable is significant at $1 \%$ level, two variables are significant at $10 \%$ level of significance. Thus, the null hypothesis is rejected. The study claimed that Occupational change is related to the socioeconomic conditions. Occupational change is due to climate change and also depends on socio- economic condition so that the socio-economic condition of the people in the coastal area of Bangladesh is changed due to climate change. The value of Cronbach's alpha is 0.6930 which is around .7 suggesting the moderate scale of reliability.

\subsection{Binary Logistic Regression.}

Table 1. Relation of socio-economic condition and occupational change

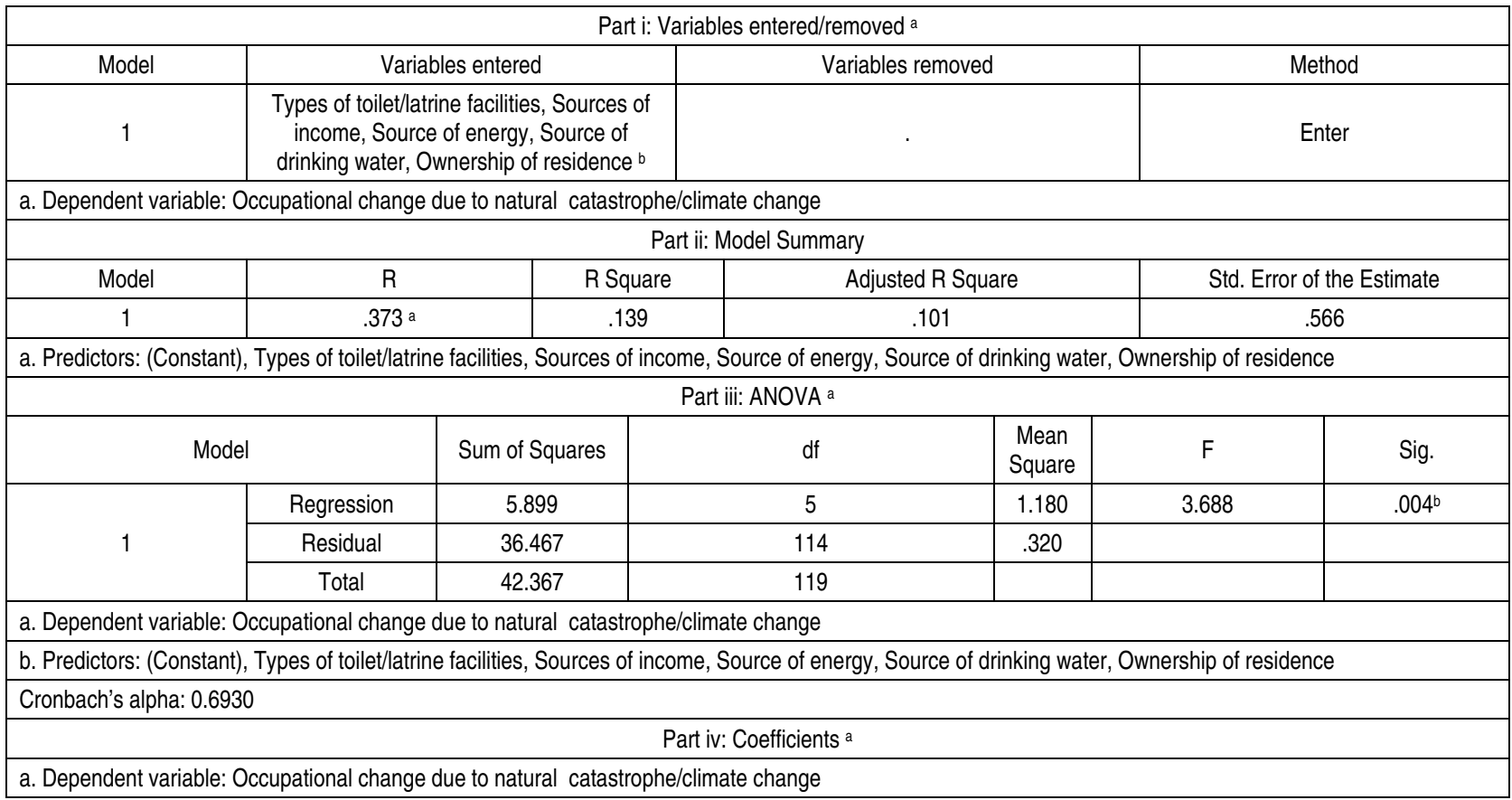

\begin{tabular}{|c|c|c|c|c|c|}
\hline \multicolumn{2}{|c|}{ Model } & \multicolumn{2}{|c|}{ Coefficients } & t-test & Sig. \\
\cline { 3 - 6 } & B & Std. Error & 15.189 & 0 \\
\hline \multirow{7}{*}{1} & (Constant) & 4.336 & 0.285 & -3.478 & 0.001 \\
\cline { 2 - 6 } & $\begin{array}{c}\text { Ownership of } \\
\text { residence }\end{array}$ & -0.35 & 0.101 & -1.774 & 0.079 \\
\cline { 2 - 6 } & $\begin{array}{c}\text { Source of drinking } \\
\text { water }\end{array}$ & -0.213 & 0.12 & 1.277 & 0.204 \\
\cline { 2 - 6 } & Sources of income & 0.093 & 0.073 & -0.374 & 0.709 \\
\cline { 2 - 6 } & Source of energy & -0.028 & 0.075 & 3.563 & 0.001 \\
\cline { 2 - 6 } & $\begin{array}{c}\text { Types of toilet/latrine } \\
\text { facilities }\end{array}$ & 0.311 & 0.087 & & \\
\hline
\end{tabular}

Source: Computed value based on Field Survey (September 2017).

Table 2 implies to the standard multiple regression of personal information of the respondents and occupational change. The adjusted R-Square value, in this case, is .579. This tells us that the five independent variables in the model account for $57.9 \%$ variance in the dependent variable that is occupational change. Based on the ANOVA part for the linear regression, the study says that this binary logistic regression model fits at $.000(p<0.001)$ level of significance.

Using the regression coefficients for independent variables and the constant term given under the column labeled B, one can construct the binary logistic regression equation for predicting Occupational change as:
Occupational change $=5.046-(.548)[$ Gender $]+$ (.084) [Educational status] - ( 1.016) [Family member $]+$ (.364) [Family type + (.148) [Occupation] - (.160) [Expenditure on education] + (.383) [Expenditure on health/medicine]

Table 2 (part iv) Coefficients shows the significant level of the independents variables: the $p$-value for beta coefficient of Gender is $.000 \quad(p<0.001)$, Educational status is $.151 \quad(p<0.15)$, Family member is $.000(p<0.001)$, Family type is .002 ( $p$ $<0.005)$, Occupation is $002(p<0.005)$, Expenditure on education is $.049(p<0.05)$, and Expenditure on health/medicine $.000 \quad(p<0.001)$. Among these seven independent variables, four variables are significant at $1 \%$ level of significance and two 
variables are significant at 5\% level of significance. Occupational change is related to the personal conditions of the respondents. Occupational change may depend on the various personal data of the respondents and if the personal position changes then the occupational change may occur. Here the influential personal data are gender, family member, family type, occupation, expenditure on education and health/medicine. As such, alternative hypothesis that occupational change is due to natural catastrophe/climate change is related to gender, educational status, family member, family type, occupation, expenditure on education, and expenditure on health/medicine is accepted. For this equation the study observed that Cronbach's a lpha is 0.7661 , which indicates that the data are reliable.

Table 2. Standard multiple factors of demography and Occupational change

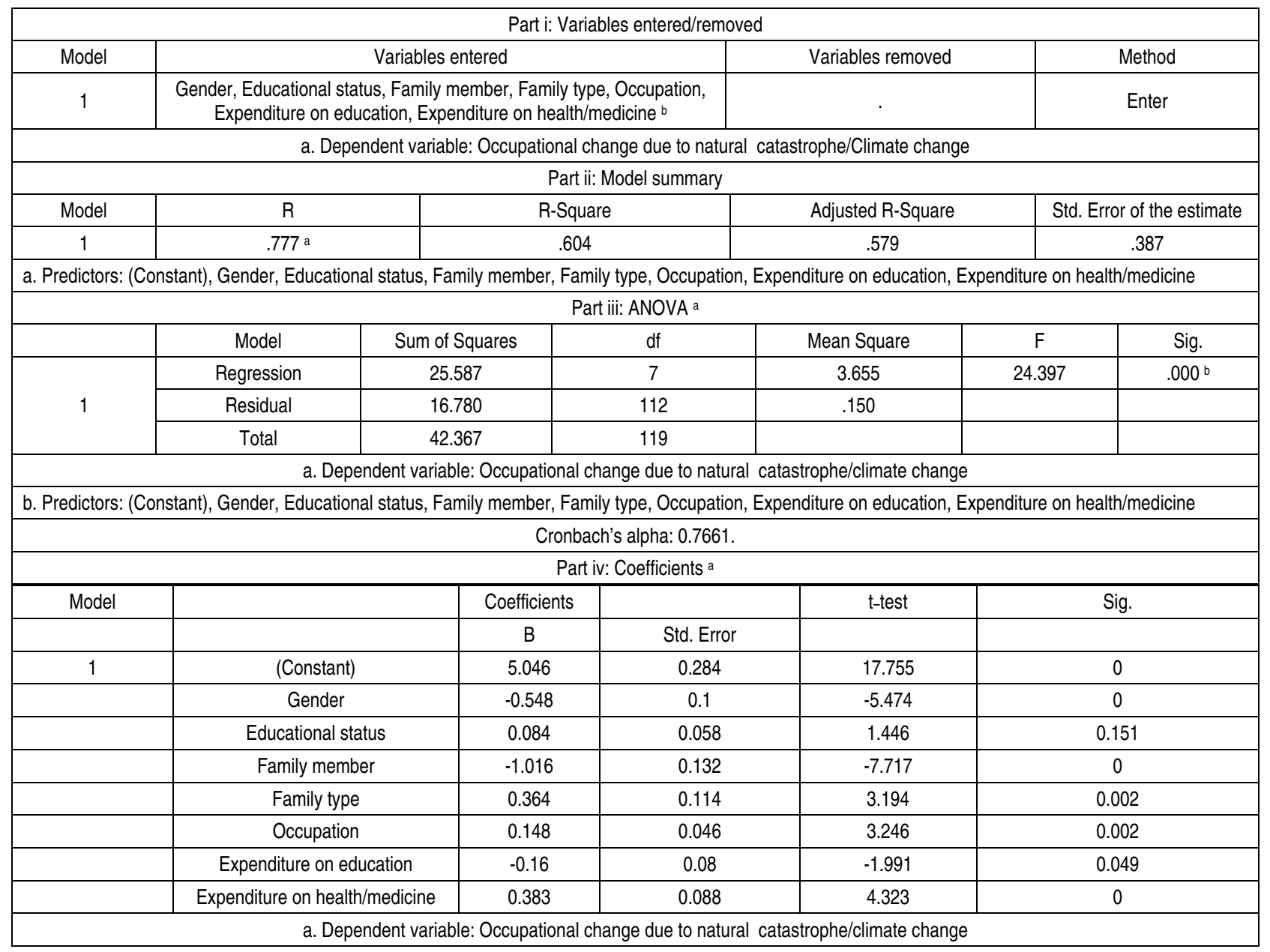

Source: Computed value based on Field Survey (September, 2017).

\subsection{Estimated results based on secondary sources.}

Table 3. Frequencies (secondary sources)

\begin{tabular}{|c|c|c|c|c|c|c|}
\hline \multicolumn{2}{|c|}{ Statistics } & VAR00001 & VAR00002 & VAR00003 & VAR00004 & VAR00005 \\
\hline \multirow{2}{*}{$\mathrm{N}$} & Valid & 12 & 12 & 12 & 12 & 12 \\
\hline & Missing & 0 & 0 & 0 & 0 & 0 \\
\hline \multicolumn{2}{|l|}{ Mean } & $5.1278 \mathrm{E} 5$ & 4.7100 & 2.2133 & 1.3933 & 8.3258 \\
\hline \multicolumn{2}{|c|}{ Median } & 4.4772E5 & 4.4650 & 1.4350 & .8200 & 7.2250 \\
\hline \multicolumn{2}{|l|}{ Mode } & $3520.00^{a}$ & $.05^{\mathrm{a}}$ & $.00^{\mathrm{a}}$ & $.00^{a}$ & $.06^{a}$ \\
\hline \multicolumn{2}{|c|}{ Std. Deviation } & 4.06482E5 & 3.10709 & 2.24547 & 1.93784 & 6.60565 \\
\hline \multicolumn{2}{|c|}{ Variance } & $1.652 \mathrm{E} 11$ & 9.654 & 5.042 & 3.755 & 43.635 \\
\hline \multicolumn{2}{|c|}{ Skewness } & 1.318 & .093 & 1.698 & 2.673 & 1.323 \\
\hline
\end{tabular}

Note: VAR00001=Affected Household.

VAR00002=Affected Time (\%)-) One Time.

VAR00003 $=$ Affected Time (\%)-)Two Time. 
VAR00004 $=$ Affected Time (\%)-) Three Time.

VAR00004 $=$ Affected Time (\%)-) Total.

Table 4. Statistics (secondary sources)

\begin{tabular}{|c|c|c|c|c|c|c|c|c|c|c|}
\hline & & $\begin{array}{c}\text { Catastrop } \\
\text { hes }\end{array}$ & Total & Crops & Livestock & Poultry & Fishery & Land & House & $\begin{array}{l}\text { Homestead } \\
\text { and forestry }\end{array}$ \\
\hline & Valid & 13 & 13 & 13 & 13 & 13 & 13 & 13 & 13 & 13 \\
\hline & Missing & 0 & 0 & 0 & 0 & 0 & 0 & 0 & 0 & 0 \\
\hline Mean & & & $2.8346 \mathrm{E} 4$ & $1.0262 \mathrm{E} 4$ & 1349.5623 & 342.2900 & 1648.3069 & 7573.8015 & 4873.3669 & 2296.3485 \\
\hline Std. E & of Mean & & 1.34739E4 & $4.98353 \mathrm{E} 3$ & 672.94602 & 170.10234 & 820.12137 & 4.22702E3 & $2.39500 \mathrm{E} 3$ & $1.17938 \mathrm{E} 3$ \\
\hline Media & & & $1.1472 \mathrm{E} 4$ & 3792.0000 & 432.2800 & 81.9300 & 338.7200 & 698.1500 & 1847.6900 & 716.3600 \\
\hline Mode & & & $249.01^{a}$ & $7.78^{\mathrm{a}}$ & $.16^{a}$ & $.11^{\mathrm{a}}$ & .00 & .00 & .00 & $.00^{\mathrm{a}}$ \\
\hline Std. D & ation & & 4.85809E4 & 1.79684E4 & 2.42634E3 & 613.31269 & 2.95699E3 & 1.52407E4 & 8.63529E3 & $4.25233 \mathrm{E} 3$ \\
\hline Varian & & & 2.360E9 & 3.229E8 & 5.887E6 & $3.762 \mathrm{E} 5$ & 8.744E6 & 2.323E8 & 7.457E7 & $1.808 \mathrm{E} 7$ \\
\hline Skewr & & & 3.187 & 3.002 & 2.776 & 2.789 & 2.743 & 2.312 & 2.887 & 2.669 \\
\hline $\begin{array}{l}\text { Std. E } \\
\text { Skewr }\end{array}$ & & & .616 & .616 & .616 & .616 & .616 & .616 & .616 & .616 \\
\hline Minim & & & 249.01 & 7.78 & .16 & .11 & .00 & .00 & .00 & .00 \\
\hline Maxim & & & 184247.34 & 66703.42 & 8772.16 & 2224.88 & 10713.99 & 49229.73 & 31676.89 & 14926.27 \\
\hline
\end{tabular}

5.3. Estimated ordinary least square regression equation on secondary sources.

$P D=f($ Year $)$,

$P D=\alpha+\beta Y e a r+\mu$,

where $P D=$ Permanent Dispersion

$\mu=$ Error term

The regression result is placed below in Table 5. The results have passed Student t-test and F statistics. Interpretation of the result is that each year coastal areas people are permanently dispersed because of climate change in Bangladesh.

Table 5. Permanent Dispersion (PD) for climate Change over each year. $P D=f($ year $)$

\begin{tabular}{|l|c|c|}
\hline & Intercept & Coefficient \\
\hline PD & -4156 & 20809.88 \\
\hline t-test & -27.09 & 27.26 \\
\hline Adjusted $R^{2}=0.986$ & F test $=743.27$ & \\
\hline
\end{tabular}

Source: Estimated.

Alternative hypothesis related to Permanent Dispersion which has occurred due to climate change was accepted.

(ii) $T D=f($ Year $)$,

where $T D=$ Temporary Dispersion,

$T D=f($ Year $)$,

$T D=\alpha+\beta$ Year $+\mu$,

where $P D=$ Temporary Dispersion

$\mu=$ Error term
The regression result is placed below. The results have passed Student $\mathrm{t}$-test and $\mathrm{F}$ statistics as can be seen from Table-6. The results have passed Student t-test and F statistics. Interpretation of the result is that each year coastal areas people are temporarily dispersed because of climate change in Bangladesh.

Table 6. Temporary Dispersion (TD) for Climate Change over each year. $T D=f($ year $)$

\begin{tabular}{|l|c|c|}
\hline & Intercept & Coefficient \\
\hline TD & -2759 & 13817.03 \\
\hline t-test & -11.98 & 12.06 \\
\hline Adjusted $\mathrm{R}^{2}=0.935$ & $\mathrm{~F}$ test $=145.40$ & \\
\hline
\end{tabular}

Source: Estimated.

Alternative Hypothesis related to Temporary Dispersion which has occurred due to climate change was accepted.

\subsection{Correlation matrix.}

First correlation matrix results are as follows for older divisional area by summing up the current divisions.

Table 8. Correlation matrix: all catastrophes

\begin{tabular}{|l|c|c|c|c|}
\hline & Dhaka & Chittagong & Khulna & Rajshahi \\
\hline Dhaka & 1 & & & \\
\hline Chittagong & 0.8215 & 1 & & \\
\hline Khulna & -0.1115 & 0.0621 & 1 & \\
\hline Rajshahi & 0.9224 & 0.8536 & -0.2430 & 1 \\
\hline
\end{tabular}

Source: Author. 
The table has been prepared from the secondary sources. Now, based on secondary sources, the study has shown population dispersion, i.e. temporary and permanent, as shown in Figure 2.

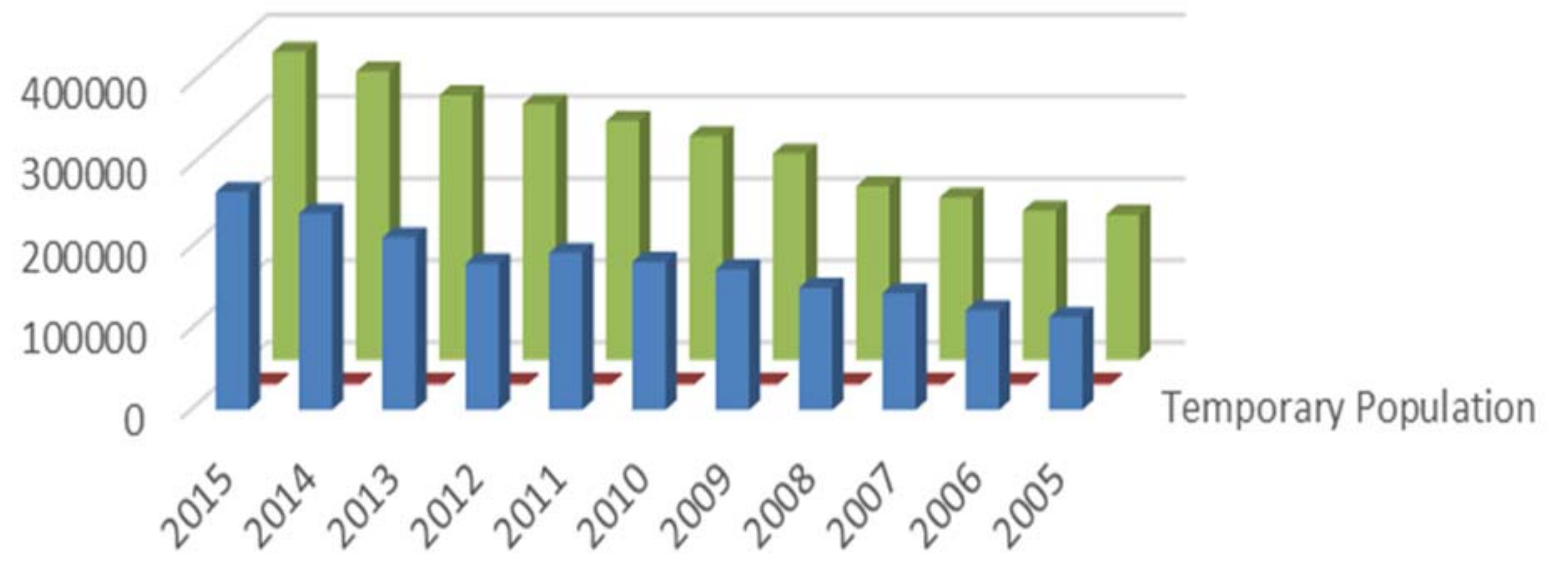

Temporary Population

Permanent Year

Permanent Population

Fig. 2. Population dispersion (temporary and permanent)

Source: BBS, chart by author.

Table 8. Correlation matrix of different categories of catastrophes affected on households

\begin{tabular}{|l|c|c|c|c|c|c|c|c|c|c|c|}
\hline & Drought & Flood & $\begin{array}{c}\text { Water } \\
\text { logging }\end{array}$ & Cyclone & Tornado & $\begin{array}{c}\text { Storm/ } \\
\text { tidal } \\
\text { surge }\end{array}$ & $\begin{array}{c}\text { Thunder } \\
\text { storm }\end{array}$ & $\begin{array}{c}\text { River/ } \\
\text { coastal } \\
\text { erosion }\end{array}$ & $\begin{array}{c}\text { Land } \\
\text { slide }\end{array}$ & Salinity & $\begin{array}{c}\text { Hail } \\
\text { storm }\end{array}$ \\
\hline Drought & 1 & & & & & & & & & & \\
\hline Flood & 0.9446 & 1 & & & & & & & & & \\
\hline Water logging & 0.9649 & 0.9354 & 1 & & & & & & & & \\
\hline Cyclone & -0.0193 & -0.0088 & 0.0476 & 1 & & & & & & & \\
\hline Tornado & 0.1476 & 0.2292 & 0.2292 & 0.9017 & 1 & & & & & & \\
\hline Storm/tidal surge & 0.2265 & 0.4173 & 0.4137 & -0.215 & -0.0357 & 1 & & & & & \\
\hline Thunderstorm & 0.1488 & 0.2282 & 0.2283 & 0.9047 & 0.9999 & -0.0455 & 1 & & & & \\
\hline $\begin{array}{l}\text { River/coastal } \\
\text { erosion }\end{array}$ & -0.0954 & 0.1853 & -0.0978 & -0.424 & -0.2479 & 0.5538 & -0.2541 & 1 & & & \\
\hline Landslide & -0.108 & 0.1753 & -0.1123 & -0.3564 & -0.1988 & 0.5335 & -0.2048 & 0.9952 & 1 & & \\
\hline Salinity & 0.5495 & 0.717 & 0.4932 & -0.2866 & -0.134 & 0.496 & -0.1364 & 0.7292 & 0.7382 & 1 & \\
\hline Hailstorm & 0.9835 & 0.9293 & 0.9637 & 0.1412 & 0.315 & 0.1818 & 0.3164 & -0.1836 & -0.1888 & 0.4591 & 1 \\
\hline $\begin{array}{l}\text { Others (fog, cold wave } \\
\text { etc.) }\end{array}$ & 0.9928 & 0.913 & 0.9738 & -0.0144 & 0.144 & 0.2259 & 0.1451 & -0.1833 & -0.20026 & 0.4608 & 0.9815 \\
\hline
\end{tabular}

Source: Author.

\section{Conclusion}

From the study, it is evident that occupational changes have been occurring at the coastal areas due to climate change and natural catastrophy. The study represented that $94.2 \%$ of people told the frequency of natural catastrophe (flood, drought, sea level rise) increasing since 2000 and the rest $(5.8 \%)$ told that natural catastrophe was not frequent in the coastal areas of Bangladesh. The study found that most of the people (95.8\%) in the coastal areas told that the salinity is increasing in their areas. About $67.5 \%$ of the people in the coastal areas said that their agricultural production was always damaged due to salinity problem and $20.0 \%$ said that their agricultural production was often damaged. The study explored that most of the crops (65.8\%), homestead (58.3\%) and fisheries (79.2\%) are greatly damaged/hampered for the over salinity problem in the coastal areas of Bangladesh. This will lead to change in the livelihood pattern of the affected person. Lázár, et al. (2015) rightly observed that due to natural catastrophe and climate change, livelihood changes, which was supported by the findings of this study.

It was found that $89.2 \%$ of people of the coastal areas told that their residence, cowshed and kitchen 
are damaged due to increase of salinity problem. The study observed that $51.7 \%$ of people said that their residence, cowshed and kitchen were often damaged $35.8 \%$ said that they were always damaged, due to the over salinity problem or natural catastrophe. The study found that the season of Bangladesh must change since 2000 due to the climate change. The study also found that $53.3 \%$ of people told that their agricultural production decreased for the season change and $20.8 \%$ people strongly agree that the agricultural production also decreased.

Approximately, $46.7 \%$ of people told that there frequently occurred water loggings and $30.0 \%$ of people said about very frequently occurred water logging in the coastal area of Bangladesh. The study showed that most of the people $(87.5 \%)$ of the coastal area told that their domestic animals were damaged in the time when the natural catastrophe occurred. Most of the people (89.17\%) in the coastal areas told that different types of diseases are increasing at the time of natural catastrophe. The study also explored that maximum (63.3\%) people agreed and $24.2 \%$ people also strongly agreed that their occupational change is due to changed for the natural catastrophe and climate change.

The study shows that that there was a strong relationship between occupational status and level of income of the people. About half (57.8\%) of the nuclear family have the income level below 5000 BDT and among them, and the joint family have an income level above 15000 BDT and also income level under 5001-10000 were $66.7 \%$.

The study found that at Cox's Bazar area no people are taking rainwater for drinking rather they mostly $(75 \%)$ drink tube well water. In the Sandip area, about $35 \%$ people are drinking rainwater and $40.0 \%$ are drinking tube well water. Besides, the people in Kuakataa mostly (62.5\%) drink tube well water. The study discovered that the occupational change may depend on the various personal data of the respondents and if the personal position changed then the income source may change.

From the binary logistic regression equation, the study can claim that occupational change is related to the socio-economic conditions. The study obtained that occupational change occurred owing to climate change and natural catastrophy. This also depended on socio-economic condition as people of the coastal areas of Bangladesh are victims of environmental change.

The study found that when the climate change was increasing, the livestock, fisheries and forestry damage also increased. The study also found that when the crops damage was increasing, the livestock's damage decreased and forestry damage also increased. The study explores that when the poultries damage was increasing the fisheries and homestead damage decreased. The binary logistic regression model for season change since 2000 due to climate change and decrease of agricultural production due to season change proved that the negative beta coefficient for decrease of agricultural production due to climate change may decrease the agricultural production in the coastal areas of Bangladesh. Each year many communities of the country have been displaced by erosion and supplementary natural catastrophe caused to live with floods and similar calamities.

The binary logistic regression equation observed that occupational change is due to climate change and that also depends on socio-economic condition so that the socio-economic condition of the people in the coastal area of Bangladesh is changed due to climate change.

Another binary logistic regression equation found that occupational change may depend on the various personal data of the respondents and if the personal position changes, the occupational change may occur. Here the influential personal data are gender, family member, family type, occupation, expenditure on education and health/medicine.

From the secondary sources, the study runs regression to assess permanent dispersion of population because of climate change. This implies that each year in coastal areas, people are permanently dispersed because of climate change in Bangladesh.

The study did another regression equation based on secondary sources. Each year in coastal areas, people are temporarily dispersed because of climate change in Bangladesh. The study observed that livelihood changes has been occurring depending on the following factors: employment type, food taking style, variation in job, environmental migration, income source change been occurred as observed from primary and secondary sources of data. The general population of Bangladesh has been living with regular perils and catastrophes for a large number of years, especially the coastal zones are enormously influenced by the unnatural change. The danger of ocean level rise because of environmental change is something which is new and possibly wrecking. Bangladesh should build up a more far-reaching perspective of its beachfront zone and how it might be best overseen in the run haul. Bangladesh requires the help of the world group so as to confront this new test. Additionally, 
the economy of the coastal region of Bangladesh enormously hampered by the expanding worldwide temperature alteration. The general population of the coastal areas has a troublesome existence for the reason for a worldwide temperature alteration in light of the fact that their rural generation, family unit and the residential creatures additionally influenced by it. Taking everything into account, one might say that a worldwide temperature alteration might be lessened by decreasing the $\mathrm{CO} 2$ from the Earth since the study definitely realizes that $\mathrm{CO} 2$ is for the most part in charge of an Earthwide temperature boost. Also, the study realizes that on the off chance that the study is not lessening the dangerous atmospheric deviation from the Earth then numerous seaside territories of the Earth might be well under the ocean. There is a fear that the rising sea level due to climate change and increased temperature may submerge the land of Bangladesh by 2050 if preventive measures are not taken as soon as possible and many people would die and lose all sources of their livelihood. Thus effective measures must be taken to minimize the dreadful impacts of climate change and improve the livelihood of people affected by climate change in the coastal areas of Bangladesh. Natural catastrophe will have adverse impact on GDP; the message between natural and factors can prominently adjust how influences can certainly arise, at least for judicious expansions in separate gripping. Social movements are needed to develop the value of economic effects arrangement problem activities than those of low-frequency typical discrepancy. Proper mitigation and adaption policy framework need to be executed by public-private and foreign fund. A systematic strategic plan needs to develop for revitalize global climate change and natural disasters so that alternative job can be created with short and long-term priority basis for the affected person so that they can at least live a decent life.

\section{Recommendations}

- Bangladesh should take effective steps at coastal areas to reduce climate change threat and also control over its phenomenon by those who are internally responsible to increase climate change.

- To create proper employment opportunity who are the victim of natural catastrophe to cope with the climate change scenario.

- GO's and NGO's of the country have to run the pograms in the coastal areas to reduce socioeconomic and humanitarian problems at the coastal areas. Catastrophe management should be done with the earliest opportunity.

- To innovate some crops, plants, rearing livestock and fishes what can be sustained in the salinity, as well as during water logging area of the country.

- Worsening river erosion downstream in Bangladesh should be stopped through taking appropriate policies and implementation without corruption.

- To conduct some training programs among the people of the coastal areas about protection from natural catastrophe.

- National Environment Policy of the years 1992 of the country needs to be updated.

- Measure should be taken to neutralize effect of water logging or river.

- For removing water logging some drainage system and dam should be developed so that through which water reduction of the country can be done.

- To reduce natural catastrophe, more trees should be planted in the coastal areas, as well as every urban and rural area of Bangladesh and throughout the world.

- Use of renewable energy and transform of energy system to one that is cleaner and less dependent on coal and other fossil fuels at the coastal areas should be arranged.

- Alternative arrangement should be arranged for livelihood of the victims of climate change and catastrophe affected people of the coastal areas of the country.

- Action plan should be prepared by the government so that in case of any natural catastrophs, short-term, as well as long-term relief and employment opportunity can be arranged at costal areas.

- Storing of rain water and use at the time of need at costal areas should be encouraged.

\section{Scope for future research}

Though climate change has many more impacts and unscrupulous effects on society and human being but the study is only trying to find out the livelihood change besides this there are many more sectors that are greatly hampered such as social impacts, physical impacts and vulnerability assessment, which can be done in future. The main shortfalls of this study are narrow study area and sample size and also only assess one impacts. There are many other scopes for the future research in this field of study. 


\section{References}

1. Adam-Poupart, A. et al. (2013). Impacts of Climate Change on Occupational Health and Safety ("Studies and Research Projects", REPORT R-775). Institut de recherche Robert-Sauvé en santé et en sécurité du travail, Canada.

2. Ahmad, Qazi Kholiquzzaman (2017). Environment, Climate Change and Water Resources. Pathak Shamabesh, Bangladesh.

3. Ahmed, F., Dipen Bhattacharya et al. (Ed.) (2009). Environmental Impacts of sea level rise on the coastal areas of Bangladesh, Climate Change and Tasks of Bangladesh. Bangladesh Poribesh Andolon (BAPA), Bangladesh Environment Network (BEN).

4. Ahmed, N., \& Glaser, M. (2016). Can Integrated Multi-Trophic Aquaculture (IMTA) adapt to climate change in coastal Bangladesh? Ocean \& Coastal Management, $132, \quad 120-131$. http://dx.doi.org/10.1016/j.ocecoaman.2016.08.017

5. Ahmed, R. (2002). Land, Soil and landscape", Bangladesh Environment Facing the $21^{\text {st }}$ century. In Philip Gain (Ed.), Society for Environment and Human Development (p.17).

6. Ahsan, K. (2008). Environmental consequences of development interventions in rural areas, 122-123.

7. Ali, M. M., \& Wakatsuki, T. (2002). Overview of Environmental and Natural Resource Dagradation of Agriculture in Bangladesh. Shimane University. Matsue: Faculty of Life and Environmental Science.

8. Alam, M. et al. (2013).Coastal livelihood adaption in changing climate Bangladesh experience of NAPA Pririty Project implementation. In Rajib Shaw et al. (Eds.), Climate Change Adaption Actions in Bangladesh (p. 258). Springer.

9. Brammer, H. (2014). Bangladesh's dynamic coastal regions and sea-level rise. Climate Risk Management, 1, 5162. http://dx.doi.org/10.1016/j.crm.2013.10.001

10. Braun, D. M. (2010). Bangladesh, India Most Threatened by Climate Change, Risk Study Finds. Retrieved June 05, 2017 from National Geographic Channel.

11. Cragg, M., \& Kahn, M. (1997). New Estimates of Climate Demand: Evidence from Location Choice. Journal of Urban Economics, 42, 261-284.

12. Dasgupta,Susmita et al. (2016). Facing The Hungry Tide: Climate Change, Livelihood Threats, And Household Responses In Coastal Bangladesh. Climate Change Economics (CCE), 7(03), 1-25.

13. Elahi, F., \& Khan, N. I. (2015). A Study on the Effects of Climate change in Bangladesh. International Journal of Environmental Monitoring and Analysis, 3(3), 118-121. http://dx.doi.org/10.11648/j.ijema.20150303.12

14. Englin, J. (1996). Estimating the Amenity Value of Rainfall. Annals of Regional Science, 30, $273-283$.

15. EPRI (2007). The pothe studyr to reduce CO2 emissions - The full portfolio. Dhaka: EPRI Energy Technology Assessment Center. Financial Express (2017), November, 18.

16. Gable, F. J. (1997). Climate Change Impacts on Caribbean Coastal Areas and Tourism. Journal of Coastal Research, 24, 49-69.

17. Goldenberg, S. (2010). US Senate's top climate sceptic accused of waging 'McCarthyite witch-hunt. Retrieved from htttps//:www.theguardian.com/environment/2010/mar/01/inhofe-climate-maccarthyitc

18. Han, M., Wu, L., Liu, Y., \& Liu, Y. (2001). Adverse Impacts of Human Development on Chinas Coastal Area: Management Issues and Implications. Journal of Coastal Research, 34, 564-572.

19. Haque, S. A. (2006). Salinity Problems and Crop Production in Coastal Regions of Bangladesh. Agricultural University. Mymensingh: Department of Soil Science.

20. Islam, A. K. M. Saiful (2016). Rising Sea Level: Challenges ahead for Bangladesh. International Centre for Climate Change and development.

21. Kabir, R., Khan, H. T., Ball, E., \& Kaldthe Studyll, C. (2014). Climate Change and public health situations. International Journal of Social Science Studies, 2(3), 109-116.

22. Kais, S. M., \& Islam, S. M. (2017). Impacts of and resilience to climate change at the bottom of the shrimp commodity chain in Bangladesh: A preliminary investigation. Aquaculture. http://dx.doi.org/10.1016/j.aquaculture.2017.05.024

23. Khan, I., Alam, F., \& Quamrul, A. (2013). The global climate change and its effect on pothe studyr generation in Bangladesh. Energy Policy, 61, 1460-1470. http://dx.doi.org/10.1016/j.enpol.2013.05.005

24. Lasco, Rodel et al. (2014). Climate risk adaptation by smallholder farmers: the roles of trees and agroforestry. Current Opinion in Environmental Sustainability, 6, 83-88. http://dx.doi.org/10.1016/j.cosust.2013.11.013

25. Lázár, Attila N. et al. (2015). Agricultural livelihoods in coastal Bangladesh under climate and environmental change - a model framework. Environmental Science: Processes \& Impacts, 17, 1018-1031. http://dx.doi.org/10.1039/C4EM00600C

26. Maddison, D. J. (2001). The Amenity Value of the Global Climate. Earthscan, London.

27. Ministry of Flood and Catastrophe Management (2009). Major Natural catastrophe in Bangladesh. Retrieved from http://www.dmb.gov.bd/past catastrophe.html

28. Nianthi, K. R. (2015). Climate Change and Its Impact on Coastal Economy of Sri Lanka. In The Global Challenge, Krishnamurthy R. et al. (Eds), Retrieved from https:/www.researchgate.net/publication/267419810

29. Rahman, Saydur,Touhiduzzaman, Md., Hasan. Irteja (2017). Coastal Livelihood Vulnerability to Climate Change: A Case Study of Char Montaz in Kuakataa District of Bangladesh. American Journal of Modern Energy, 3(4), 58-64. 
30. Roback, J. (1982). Wages, Rents and the Quality of Life. Journal of Political Economy, 90, 1257-1278.

31. Rojas-Downing, M. M., Nejadhashemi, A. P., Harrigan, T., \& Woznick, S. A. (2017). Climate change and livestock: Impacts, adaptation, and mitigation. Climate Risk Management, 16, 145-163.

32. Saravanavel, P. (1992). Research Methodology (4 ${ }^{\text {th }}$ ed.). Allahbad: Kitab Mahal.

33. Scheaffer, R. L., Mendenhall, W., \& Ott, L. (1995). Elementary Survey Sampling. Washington, D.C: Duxbury Press.

34. Selvaraju, R. et al. (2006). Livelihood adaptation to climate variability and change in drought-prone areas of Bangladesh-Developing institutions and options - Case study. Asian catastrophe preparedness center Food and agriculture organization of the United Nations, Rome.

35. Sharma, B. V., Prasad, D. R., \& Satyanarayana, P. (1983). Research Methods in Social Sciences. New Delhi: Sterling Publishers Pvt. Ltd.

36. Shamsuddoha, Md., \& Chowdhury, Rezaul Karim (2007). Climate Change Impact and catastrophe Vulnerabilities in the Coastal Areas of Bangladesh. COAST Trus., November.

37. Sing, Y. K. (2006). Fundamentals of Research Methodology and Statistics. New Delhi: New Age International Publishers.

38. Smith, V. K. (1983). The Role of Site and Job Characteristics in Hedonic Wage Models. Journal of Urban Economics, 13, 296-321.

39. Stavins, Robert N. (Ed.) et al. (2013). Economics as climate change and environmental elected papers. Elgar Publishing Limited.

40. U.S. Environmental Protection Agency (2011). Climate ChangeGreenhouse Gas Emissions, 2011 Inventory of Greenhouse Gas Emissions and Sinks prepared by EPA for the years 1990 through 2009.

41. UNDP (2008). Bangladesh Reducing Development Risks in Changing Climate. Dhaka, Bangladesh: United Nations Development Program.

42. Wright, H. (2016). What does the IPCC report say about climate change in Bangladesh? International Centre for Climate Change and development, February, 16. 


\section{Appendix}

Table 1. Demographic information with frequency level and percentage

\begin{tabular}{|c|c|c|c|}
\hline Factors & Category & Frequency & Percent \\
\hline \multirow{5}{*}{ Age of the respondents } & Below 25 & 14 & 11.7 \\
\hline & $26-35$ & 39 & 32.5 \\
\hline & $36-45$ & 44 & 36.7 \\
\hline & $46-55$ & 21 & 17.5 \\
\hline & Above 55 & 2 & 1.7 \\
\hline \multirow{2}{*}{ Gender distribution of the respondents } & Male & 91 & 75.8 \\
\hline & Female & 29 & 24.2 \\
\hline \multirow{3}{*}{ Marital status of the respondents } & Single & 13 & 10.8 \\
\hline & Married & 97 & 80.8 \\
\hline & Widow/Widower & 10 & 8.3 \\
\hline \multirow{3}{*}{ Family member of the respondents } & Below 4 & 29 & 24.2 \\
\hline & $5-7$ & 89 & 74.2 \\
\hline & Above 7 & 2 & 1.7 \\
\hline \multirow{6}{*}{ Occupation of the respondents } & Farmer & 23 & 19.2 \\
\hline & Day labor & 29 & 24.2 \\
\hline & Housewife & 12 & 10.0 \\
\hline & Fisherman & 8 & 6.7 \\
\hline & Service/Job & 20 & 16.7 \\
\hline & Business & 23 & 19.2 \\
\hline \multirow{5}{*}{ Personal income of the respondents } & No Income & 29 & 24.2 \\
\hline & Below 5000 & 20 & 16.7 \\
\hline & $5001-10000$ & 50 & 41.7 \\
\hline & $10001-15000$ & 17 & 14.2 \\
\hline & Above 15000 & 4 & 3.3 \\
\hline \multirow{4}{*}{ Head of the household } & Self & 61 & 50.8 \\
\hline & Father & 23 & 19.2 \\
\hline & Husband & 29 & 24.2 \\
\hline & Son & 7 & 5.8 \\
\hline \multirow{4}{*}{ Educational qualification of the head of the household } & Illiterate & 29 & 24.2 \\
\hline & Primary & 56 & 46.7 \\
\hline & Secondary & 27 & 22.5 \\
\hline & Tertiary & 8 & 6.7 \\
\hline \multirow{5}{*}{ Occupation of the HHH (head of household) } & Farmer & 47 & 39.2 \\
\hline & Day labor & 18 & 15.0 \\
\hline & Fisherman & 21 & 17.5 \\
\hline & Service/Job & 8 & 6.7 \\
\hline & Business & 26 & 21.7 \\
\hline \multirow{4}{*}{ Household structure of the respondents } & Kacha/Mud & 29 & 24.2 \\
\hline & Jupri/Hut & 42 & 35.0 \\
\hline & Concrete & 8 & 6.7 \\
\hline & Semi-concrete & 41 & 34.2 \\
\hline \multirow{4}{*}{ Household income of the respondents } & Below 10000 & 43 & 35.8 \\
\hline & $10001-15000$ & 69 & 57.5 \\
\hline & $15001-20000$ & 5 & 4.2 \\
\hline & Above 20000 & 3 & 2.5 \\
\hline \multirow{3}{*}{$\begin{array}{l}\text { Expenditure on food of the household of coastal area of } \\
\text { bangladesh }\end{array}$} & Below 5000 & 13 & 10.8 \\
\hline & $5001-8000$ & 81 & 67.5 \\
\hline & Above 8000 & 26 & 21.7 \\
\hline \multirow{2}{*}{ Expenditure on clothes } & Below 500 & 50 & 41.7 \\
\hline & Above 500 & 70 & 58.3 \\
\hline \multirow{2}{*}{ Expenditure on transport } & Below 500 & 54 & 45.0 \\
\hline & Above 500 & 66 & 55.0 \\
\hline
\end{tabular}


Table 1 (cont.). Demographic information with frequency level and percentage

\begin{tabular}{|c|c|c|c|}
\hline Factors & Category & Frequency & Percent \\
\hline \multirow{4}{*}{$\begin{array}{l}\text { Expenditure of the household on education of coastal areas } \\
\text { of Bangladesh }\end{array}$} & No cost & 41 & 34.2 \\
\hline & Below 500 & 37 & 30.8 \\
\hline & $501-1000$ & 34 & 28.3 \\
\hline & Above 1000 & 8 & 6.7 \\
\hline \multirow{3}{*}{ Expenditure of health/medicine } & Below 1000 & 55 & 45.8 \\
\hline & $1001-2000$ & 47 & 39.2 \\
\hline & Above 2000 & 18 & 15.0 \\
\hline \multirow{3}{*}{ Expenditure of miscellaneous } & Below 1000 & 74 & 61.7 \\
\hline & $1001-2000$ & 38 & 31.7 \\
\hline & Above 2000 & 8 & 6.7 \\
\hline \multirow{3}{*}{ Ownership of residence of the respondents } & Own & 88 & 73.3 \\
\hline & Rented & 8 & 6.7 \\
\hline & Free & 24 & 20.0 \\
\hline \multirow{3}{*}{$\begin{array}{l}\text { Main source of drinking water of the people in the coastal } \\
\text { areas of Bangladesh }\end{array}$} & Deep well water & 29 & 24.2 \\
\hline & Tube well & 71 & 59.2 \\
\hline & Rainwater & 20 & 16.7 \\
\hline \multirow{4}{*}{ Main sources of income of the household } & Agriculture & 69 & 57.5 \\
\hline & Business & 26 & 21.7 \\
\hline & Service & 8 & 6.7 \\
\hline & Day labor & 17 & 14.2 \\
\hline \multirow{3}{*}{$\begin{array}{l}\text { Main source of energy of the household of the coastal areas } \\
\text { of Bangladesh }\end{array}$} & Electricity & 72 & 60.0 \\
\hline & Solar power & 11 & 9.2 \\
\hline & Kerosene & 37 & 30.8 \\
\hline \multirow{4}{*}{ Types of toilet/latrine facilities in the coastal areas } & Concrete/slab (water sealed) & 18 & 15.0 \\
\hline & Concrete/slab (not water sealed) & 41 & 34.2 \\
\hline & Katcha & 35 & 29.2 \\
\hline & Open space & 26 & 21.7 \\
\hline \multirow{6}{*}{ Multiple response of main sources of fuel for cooking } & Wood/bamboo & 112 & $93.3 \%$ \\
\hline & Cow dung & 60 & $50.0 \%$ \\
\hline & Leaves/straw & 78 & $65.0 \%$ \\
\hline & Biogas & 8 & $6.7 \%$ \\
\hline & Kerosene & 21 & $17.5 \%$ \\
\hline & Electricity & 43 & $35.8 \%$ \\
\hline \multirow{3}{*}{$\begin{array}{l}\text { Perception about rising of global mean temperature since } \\
2000\end{array}$} & Risen & 38 & 31.7 \\
\hline & Stayed the same & 22 & 18.3 \\
\hline & Unsure & 60 & 50.0 \\
\hline \multirow{4}{*}{$\begin{array}{l}\text { Perception of increase of global mean temperature by } \\
\text { contribution of human activity }\end{array}$} & Significantly contributed by humans & 45 & 37.5 \\
\hline & Moderately contributed by humans & 26 & 21.7 \\
\hline & Not at all-only by natural causes & 3 & 2.5 \\
\hline & Unsure & 46 & 38.3 \\
\hline \multirow{4}{*}{ Decision about Increasing of climate change since 2000} & Strongly disagree & 8 & 6.7 \\
\hline & Undecided & 19 & 15.8 \\
\hline & Agree & 55 & 45.8 \\
\hline & Strongly agree & 38 & 31.7 \\
\hline \multirow{2}{*}{$\begin{array}{l}\text { Thinking about occurring natural catastrophe due to climate } \\
\text { change }\end{array}$} & Yes & 73 & 60.8 \\
\hline & No & 47 & 39.2 \\
\hline \multirow{2}{*}{ Thinking about rapid climate change due to climate change } & Yes & 73 & 60.8 \\
\hline & No & 47 & 39.2 \\
\hline \multirow{2}{*}{$\begin{array}{l}\text { Frequency of natural catastrophe (flood, drought, sea level } \\
\text { rise) Increasing since } 2000\end{array}$} & Frequent & 113 & 94.2 \\
\hline & Not frequent & 7 & 5.8 \\
\hline \multirow{2}{*}{$\begin{array}{l}\text { Increase salinity in the coastal area of bangladesh since } \\
2000\end{array}$} & Increase & 115 & 95.8 \\
\hline & Not increase & 5 & 4.2 \\
\hline
\end{tabular}


Table 1 (cont.). Demographic information with frequency level and percentage

\begin{tabular}{|c|c|c|c|}
\hline Factors & Category & Frequency & Percent \\
\hline \multirow{4}{*}{ Damage agricultural production by salinity problem } & Always & 81 & 67.5 \\
\hline & Often & 24 & 20.0 \\
\hline & Sometimes & 7 & 5.8 \\
\hline & Rarely & 8 & 6.7 \\
\hline \multirow{6}{*}{$\begin{array}{l}\text { Multiple responses of damaged/hampered different sector } \\
\text { by salinity problem }\end{array}$} & Crops & 79 & $65.8 \%$ \\
\hline & Livestock's & 37 & $30.8 \%$ \\
\hline & Poultries & 17 & $14.2 \%$ \\
\hline & Fisheries & 95 & $79.2 \%$ \\
\hline & Homestead & 70 & $58.3 \%$ \\
\hline & Forestry & 53 & $44.2 \%$ \\
\hline \multirow{2}{*}{$\begin{array}{l}\text { Damage of residence, cowshed and kitchen by the salinity } \\
\text { problem/natural catastrophe }\end{array}$} & Yes & 107 & 89.2 \\
\hline & No & 13 & 10.8 \\
\hline \multirow{3}{*}{$\begin{array}{l}\text { Frequency of damage of residence, cowshed and kitchen by } \\
\text { the salinity problem/natural catastrophe }\end{array}$} & Always & 43 & 35.8 \\
\hline & Often & 62 & 51.7 \\
\hline & Sometimes & 15 & 12.5 \\
\hline \multirow{2}{*}{ Season change due to climate change since 2000} & Change & 92 & 76.7 \\
\hline & No Change & 28 & 23.3 \\
\hline \multirow{4}{*}{ Decrease agricultural production due to season change } & Disagree & 13 & 10.8 \\
\hline & Undecided & 18 & 15.0 \\
\hline & Agree & 64 & 53.3 \\
\hline & Strongly agree & 25 & 20.8 \\
\hline \multirow{4}{*}{ Frequency of occurring water logging in coastal area } & Less frequently & 18 & 15.0 \\
\hline & Moderate frequently & 10 & 8.3 \\
\hline & Frequently & 56 & 46.7 \\
\hline & Very frequently & 36 & 30.0 \\
\hline \multirow{2}{*}{ Domestic animals damage due to natural catastrophe } & Damage & 105 & 87.5 \\
\hline & No damage & 15 & 12.5 \\
\hline \multirow{2}{*}{$\begin{array}{l}\text { Frequency of increasing Illness in the time of natural } \\
\text { catastrophe }\end{array}$} & Increase & 107 & 89.17 \\
\hline & Not increase & 13 & 10.83 \\
\hline \multirow{3}{*}{$\begin{array}{l}\text { Change livelihood pattern due to natural catastrophe/climate } \\
\text { change }\end{array}$} & Undecided & 15 & 12.5 \\
\hline & Agree & 76 & 63.3 \\
\hline & Strongly agree & 29 & 24.2 \\
\hline
\end{tabular}

Source: Computed value based on Field Survey (September 2017). 